\title{
Sediment Augmentation for River Rehabilitation and Management-A Review
}

\author{
Christian Mörtl * (D) and Giovanni De Cesare $\mathbb{C}$ \\ EPFL, Platform of Hydraulic Constructions, CH-1015 Lausanne, Switzerland; giovanni.decesare@epfl.ch \\ * Correspondence: christian.moertl@epfl.ch
}

check for

updates

Citation: Mörtl, C.; De Cesare, G Sediment Augmentation for River Rehabilitation and Management-A Review. Land 2021, 10, 1309. https:// doi.org/10.3390/land10121309

Academic Editor: Carla Rolo Antunes

Received: 20 October 2021

Accepted: 24 November 2021

Published: 27 November 2021

Publisher's Note: MDPI stays neutral with regard to jurisdictional claims in published maps and institutional affiliations.

Copyright: (c) 2021 by the authors. Licensee MDPI, Basel, Switzerland. This article is an open access article distributed under the terms and conditions of the Creative Commons Attribution (CC BY) license (https:// creativecommons.org/licenses/by/ $4.0 /)$.
Abstract: Sediment management is an important part of river rehabilitation and management. Global case studies provide a growing number of examples of successful sediment augmentation measures that can counter the adverse effects of disturbed sediment regimes. The initial river state and the objectives of the reported measures can vary largely, however. In this review, a summary of selected case studies is presented, and an objective-focused classification of sediment augmentation measures is introduced. Case-specific restrictions, design approaches and assessment methods based on the literature review and our own experience from working in the field are presented. This summary aims to provide an overview on up-to-date knowledge for applied river rehabilitation and management.

Keywords: sediment augmentation; sediment management; eco-morphology; river rehabilitation; bedload budget; channel dynamics; riverbed structure; interstitial spawning habitat

\section{Introduction}

The sediment regime of a river is a fundamental driver of the fluvial ecosystem and is therefore a key subject of focus for its rehabilitation and management [1]. Bedload sediment deficit is a common phenomenon downstream of dams [2] and in areas of extensive gravel mining [3]. It promotes progressive river bed incision [4] and the coarsening of the bed material [5] until a static armour layer develops [6]. It also leads to an overall reduction of morphological channel dynamics [7].

Sediment-starved rivers can develop a number of unwanted morphological effects, such as decreased river bank stability [8], local scour [9] or groundwater overdrafting [10]. Sediment deficit also induces negative ecological effects, such as missing spawning grounds [11] and dynamic habitat spaces for fish [12]. With a constant low flow regime, suspended fine particles settle into the open pore spaces of the static bed layer which can lead to the clogging of the river bed [13]. Clogging can inhibit hyporheic exchange processes between a river and the adjacent groundwater [14] and can amplify adverse ecological effects [15].

The artificial supply of sediment, commonly referred to as sediment augmentation or sediment replenishment, is a method that is increasingly used to address sediment-related issues in regulated rivers. The term sediment augmentation is used here as general term, because it is free of implications for its design and objectives. The design of sediment augmentation measures (SAMs) depends on the defined objectives and the morphological, hydrological, and ecological conditions of the river.

Sediment augmentation has been widely practised and documented over the last decades, particularly in Japan, the USA and in Europe [16]. Due to the availability of data and the good representation of varying measures, this study focuses on experiences from case studies and related publications from those three regions. The main objective of this study is to summarize case-specific restrictions, design approaches and assessment methods for SAMs.

In this paper, examples of representative case studies are provided for each region (Section 2). Then, the principal objectives of SAMs are outlined (Section 3) and poten- 
tial restrictions in the target flow reach are explained (Section 4). Case-specific design recommendations (Section 5) and different assessment approaches (Section 6) are then presented. In the conclusion (Section 7), the achievements and shortcomings of this study are discussed.

\section{Case Studies}

\subsection{Japan}

In Japan, SAMs are performed frequently downstream of nearly 25\% of its dams [17], with the overall aim of reducing reservoir sedimentation and re-establishing sediment continuity across reservoirs. Coarse sediments are most commonly dredged out at check dams at the head of the reservoirs and placed in high-flow stockpiles at the downstream reach, to be mobilized during controlled natural or artificial floods [17]. The median grain size of this material ranges from about $0.25 \mathrm{~mm}$ to $28 \mathrm{~mm}$ in diameter $\left(\mathrm{d}_{50}\right)$, depending on the dredging location [18]. Over the last decade, the focus of research has turned towards the mitigation of adverse morphological effects and riverine habitat revitalization in the downstream reaches of dams.

Downstream of the Nunome Dam at the Nunome River, sediment augmentation, coupled with floodplain habitat restoration, was found to be successful at restoring bedload transportation and the associated habitat [19]. In addition, riffle structures from previous SAMs were found to have a good retention capacity that made them useful for removing reservoir-derived plankton, which then subsequently contributed to a richness of macroinvertebrates species [20]. Downstream of the Murou Dam at the Uda River, improvements in the riverbed formation, riverbed materials, benthic organisms and algae were tracked in a four year survey of annual sediment augmentation [21].

\subsection{USA}

In the USA, SAMs have primarily focused on spawning habitat rehabilitation (SHR) for salmonids, and measures have been implemented episodically by various government agencies since the 1960 s and 1970s [22]. The $d_{50}$ of supplied material in the main case studies lies between $32 \mathrm{~mm}$ and $64 \mathrm{~mm}$, and is thereby in the upper region of the sizes for salmonid spawning gravels $\left(\mathrm{d}_{50}=5.4 \mathrm{~mm}-78 \mathrm{~mm}\right)$ [23].

The most famous study site is the Trinity River in California, where research efforts are dedicated towards obtaining a process-based understanding of the generation of in-channel morphological features, such as spawning riffles, through upstream sediment supply $[20,24,25]$. The increase in spawning substrates and spawning bed enhancements have been investigated with different design objectives and validation methods for SHR [26]. Both efforts combined are suggested to be successful at enhancing spawning habitats [27-29] and beneficial to macroinvertebrate assemblages [30]. Improvements in spawning habitat quality for salmon and steelhead at the Feather River in California were tracked after the direct placement of suitable spawning substrates in the side channel and after spawning riffle construction in the main channel [31].

\subsection{Europe}

In Europe, where most rivers are heavily regulated and modified around settlements and infrastructure, SAMs focus on both morphological changes and ecological upgrading. The wide range of project objectives at varying scales has led to a growing diversity of design and assessment strategies.

A positive impact on the morphological conditions was achieved with a single SAM when local riverbed incisions were reduced at the Buëch River in France [32]. Studies on consecutive augmentation at reach scale were performed over a period of four years at the Rhine River [33] and over almost two decades at the Isar River in Germany [34]. At the rehabilitation section of the Rhine, the augmentation measure contributed to local habitat diversification, but sediment starvation conditions reappeared after more than five years [35]. 
The local impact on biological communities was positive, with the gravel augmentation tending to promote the taxonomic richness of macroinvertebrate communities [36].

Basin-scale observations of the Rhine River found that, in large river systems, natural erosion and sedimentation phenomena still dominated present-day morphodynamics, even though today SAMs represent the river's biggest source of gravel and cobbles [37]. The total mass of introduced material amounts to approximately 8.4 million tons of allochthonous sediment (mainly gravel) [38]. In the lower reach of the Rhine, it was shown that present-day degradation rates would have been much higher without the upstream sediment augmentation [38]. Another successful example at the catchment scale is the rehabilitation project of the River Ehen in north-west England [39]. Sediment augmentation was performed by reconnecting a formerly diverted headwater sub-catchment back to its mainstem. The reconnected tributary has a significant level of control over coarse sediment supply and dynamics and has proven to be an important source of fine material [40].

The ecomorphological state of a river, which can be adequately represented by e.g., the Hydro-Morphological Index of Diversity (HMID) [41],was reported to improve downstream of a single SAM in a residual flow reach of the Sarine River in Switzerland [42,43]. At the Drôme River in France, investigations on basin-scale environmental changes suggested that sediment augmentation caused by floodplain deforestation can potentially still negatively impact the ecological value of the river network, even while morphological diversity increases [44].

\subsection{Representative Data Survey}

While SAMs have been implemented in river engineering since at least half a century ago, the number of related scientific papers has increased significantly only since the beginning of the new millennium, with only a small percentage of the described measures being related to a restoration action [45]. Scattered information can be found in company reports, newspapers or other public media, but this requires careful crosschecking in each individual case.

Figure 1 summarizes the data of three representative, scientific case studies of single SAMs that have been implemented in Japan, USA and Europe since the year 2000 (see Table A1 in the Appendix A). The volume of effective sediment augmentation represents the volume entrained by the first flood event after installation.

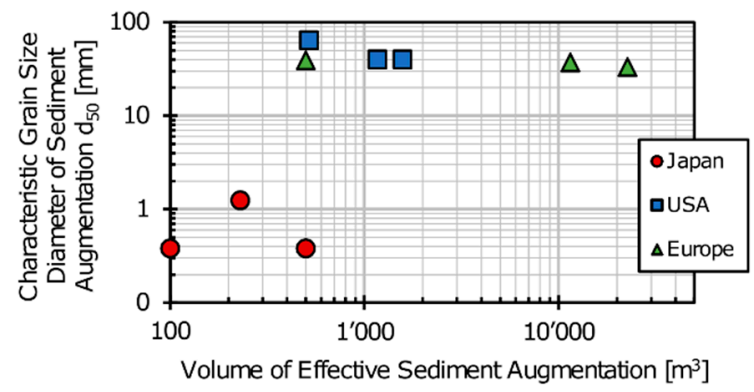

(a)

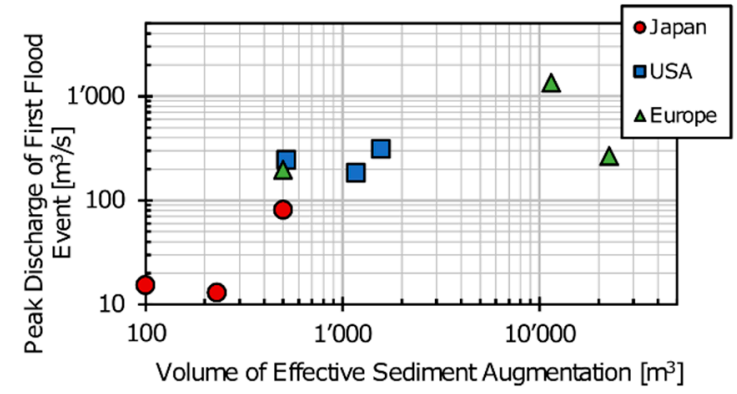

(b)

Figure 1. Data concerning single sediment augmentation measures from three regions over the last two decades: (a) grain size diameter and $(\mathbf{b})$ peak discharge against the volume of effective sediment augmentation. For data and sources, see Table A1.

In this data set, the grain diameter of augmented sediments in the Japanese rivers is small compared to the other two regions. The size of the material represents the fact that the mixture had been dredged out at the head of the reservoir. In the case studies from Europe and USA, the material is dredged out at the floodplains, which contributes to the larger bedload sizes during pre-dam conditions.

Japanese mountain rivers generally have low concentrations of suspended sediment and low bedload yields, except during periods of heavy rainfall activity [46]. The volume of 
augmented material is therefore relatively low. In the examples from Europe, volumes vary with each project and are generally high, as SAMs there focus on a range of morphological changes, except for SHR, which is the main focus of the examples from the USA.

The peak discharge of the mobilizing flood event increases with the volume of augmented material and the average diameter of grains across all regions, because this process is typically designed to generate sufficient erosion and help the river transport more of the augmented sediments.

\section{Principal Objectives}

The different types of SAMs are commonly classified according to their injection method [47]. With largely varying conditions and objectives in river rehabilitation [48], this classification does not provide enough comparability between different projects for system-scale analysis.

Here, four principal rehabilitation and management foci for SAMs are defined: (1) bedload budget, (2) channel dynamics, (3) riverbed structure and (4) interstitial (spawning) habitat. The objectives related to these targets focus on (eco-)morphological improvements on different spatial and temporal scales (Figure 2).

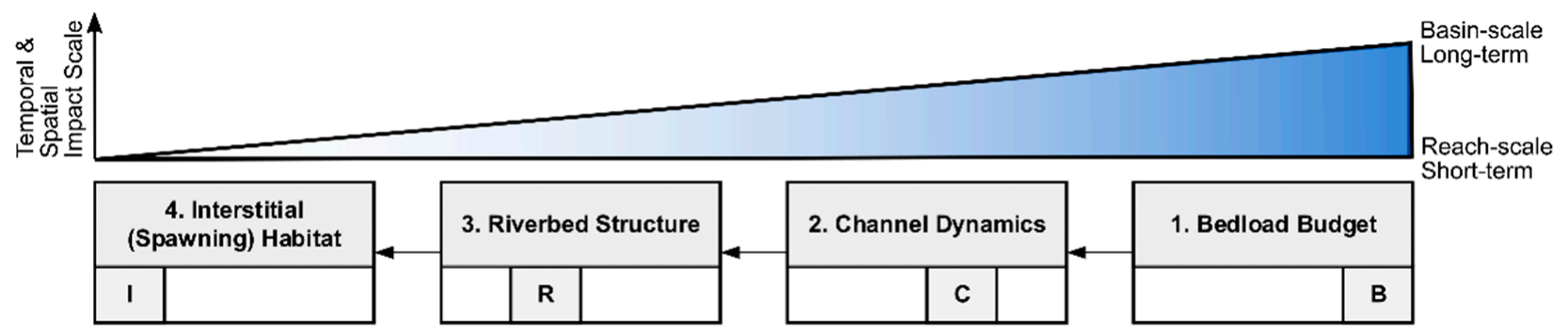

Figure 2. Principal rehabilitation and management foci of sediment augmentation measures.

For example, an SAM that focuses on balancing the bedload budget is designed for long-term, basin-scale eco-morphological improvement (e.g., [38]). The combination with other rehabilitation measures, such as generating ecological flood regimes $[49,50]$ and creating sufficient space for the river corridor [51], establishes the prerequisite for the natural evolution towards a sustainable, eco-morphological reference state. On the other hand, an augmentation measure that focuses on SHR can produce positive, reach-scale effects in the short term (e.g., [52]). This measure can be applied at river sections with hydro-morphological restrictions, for example, in residual flow sections. The expected positive impacts are less sustainable, e.g., lasting only 5-6 years [52].

\subsection{Bedload Budget}

The most practised application of sediment augmentation has the primary objective of balancing the bedload budget on a basin scale [37]. The intention is to control the equilibrium channel geometry in gravel rivers [53] and to mitigate the various adverse morphological and ecological effects in sediment starved rivers (see Section 1). In this context, the SAM can be referred to as a "replenishment" measure, as it is used to replenish the natural budget. The augmentation is usually initiated at several spots along the river, typically downstream of sediment barriers (lakes, reservoirs) and upstream of continuous river sections with sufficiently strong hydro-morphological processes, to ensure the periodic downstream migration of the injected sediment pulses. A large-scale response from the river system, especially in large river systems, such as the Rhine, can be expected only after decades of continuous replenishment efforts (e.g., [54]). The morphological goal of an SAM in this context is at first to mobilize the injected bedload material and then to continuously enhance sediment pulse dynamics in the river through constant repetition [35]. 


\subsection{Channel Dynamics}

The promotion of channel dynamics can be another objective of SAMs. With sufficient aggradation in the active channel, sediment supply rates can become a driving factor for lateral mobility [55]. When designed properly, the augmented sediment can ensure that there is enough sediment load during formative flow to promote lateral channel migration [56], e.g., for dynamic river widenings [55] and the creation [24] and maintenance [57] of channel bars. Active channel dynamics promote the evolution of new dynamic habitat spaces [58], e.g., river banks for riparian vegetation, and increased flow complexity in the river [59]. The target impact section is usually a larger restoration site or an unimpaired flow stretch, and the objectives are defined in a timeframe of years. The morphological goal of an SAM in this context is to provide enough sediment to trigger and amplify lateral erosion and regionally or locally reshape the river planform shape.

\subsection{Riverbed Structure}

When the objective is to enhance the riverbed structure at the scale of a defined impact reach, sediment augmentation can promote several positive, eco-morphological processes, even under severe hydro-morphological restrictions. For example, in residual flow reaches that are downstream of large dams, new riffle structures can be created to free the benthic zone from the nuisance caused by attached algae that travel from the reservoir [20]. Furthermore, the hydro-morphological diversity can be increased [42,43]. Another theoretical benefit of sediment augmentation for the riverbed structure is the deconsolidation and mobilization of the top layer [60] and thus the reduction of clogging of the interstitial pore space. The target impact section of an individual measure can stretch for several hundred meters downstream of the point of injection, with the potential for positive effects to emerge soon after the first mobilizing flood. The morphological goal of an SAM in this context is to create new-or restructure existing-longitudinal bedforms, such as pools, riffles or channels.

\subsection{Interstitial (Spawning) Habitat}

Where bed substrate quality is low and poorly suited for macroinvertebrate or spawning habitat, SAMs can be applied with the objective of locally improving interstitial habitats [25,27]. Different species have different habitat requirements related to substrate layer thickness, grain size and diameter and fine content (Section 5.1), as well as water depth flow velocities and bedforms. The design of gravel augmentation needs to be adapted according to the requirements of the target or dominant species. For example, for brown trout, spawning riffles were successfully constructed in the Moosach River in south Germany after the introduction of additional spawning gravel $(16-32 \mathrm{~mm}$, percentage fines $<1 \%$ ) [52]. SAMs with this objective typically target small areas of spawning ground and can trigger an immediate (seasonal) response from the target species. The morphological goal for interstitial habitat revitalization with such an SAM is to deposit suitable substrate in sufficient quantities at the location of potential habitat grounds.

\subsection{A Conceptual Framework for Objective-Focused Design}

Table 1 represents a conceptual framework for the pre-assessment of potentially relevant restrictions, design approaches and assessment methods for each of the defined foci and their related objectives (1-4), which are treated individually. The framework that we introduce is based on the literature and our experience in the field. 
Table 1. Relevant restrictions, design approaches and assessment methods for four principal rehabilitation and management objectives of sediment augmentation measures.

\begin{tabular}{|c|c|c|c|c|c|}
\hline \multirow[t]{8}{*}{$\begin{array}{l}\text { Principal } \\
\text { Objectives }\end{array}$} & $\begin{array}{l}\text { Bedload Budget (B) } \\
\text { Channel Dynamics (C) } \\
\text { Riverbed Structure (R) } \\
\text { Interstitial (Spawning) Habitat (I) }\end{array}$ & $\mathbf{I}$ & $\mathbf{R}$ & $\mathrm{C}$ & B \\
\hline & $\begin{array}{l}\text { Restrictions } \\
\text { Identify relevant objectives for existing restrictions }\end{array}$ & & & & \\
\hline & Constant low residual flow discharge & $\checkmark$ & $\checkmark$ & & \\
\hline & No recurring major morphological discharges & $\checkmark$ & $\checkmark$ & & $\checkmark$ \\
\hline & Sediment discontinuities & $\checkmark$ & $\checkmark$ & $\checkmark$ & \\
\hline & Lateral limitations for river widenings & $\checkmark$ & $\checkmark$ & & $\checkmark$ \\
\hline & None of the above & $\checkmark$ & $\checkmark$ & $\checkmark$ & $\checkmark$ \\
\hline & $\begin{array}{l}\text { Design Approaches } \\
\text { Identify relevant design approaches for defined objectives }\end{array}$ & & & & \\
\hline \multirow{3}{*}{$\begin{array}{l}\text { Sediment } \\
\text { Properties }\end{array}$} & Spawning substrate & $\checkmark$ & & & \\
\hline & Sediment mix & & $\checkmark$ & $\checkmark$ & \\
\hline & Bedload material & & $\checkmark$ & $\checkmark$ & $\checkmark$ \\
\hline \multirow{3}{*}{ Volume } & Missing spawning substrate & $\checkmark$ & & & \\
\hline & Morpho-dynamically required volume & & $\checkmark$ & $\checkmark$ & \\
\hline & Bedload deficit & & & $\checkmark$ & $\checkmark$ \\
\hline \multirow{5}{*}{$\begin{array}{l}\text { Injection } \\
\text { Method }\end{array}$} & In-channel injection & $\checkmark$ & $\checkmark$ & & \\
\hline & Stockpile & $\checkmark$ & $\checkmark$ & $\checkmark$ & $\checkmark$ \\
\hline & High-flow constant injection & $\checkmark$ & $\checkmark$ & $\checkmark$ & $\checkmark$ \\
\hline & Induced riverbank erosion & & $\checkmark$ & $\checkmark$ & $\checkmark$ \\
\hline & Reactivation of old side channels & & & & $\checkmark$ \\
\hline \multirow{4}{*}{$\begin{array}{l}\text { Mobilization } \\
\text { Event }\end{array}$} & None & $\checkmark$ & $\checkmark$ & & \\
\hline & Natural flood & & $\checkmark$ & $\checkmark$ & $\checkmark$ \\
\hline & Environmental flow release & $\checkmark$ & $\checkmark$ & $\checkmark$ & $\checkmark$ \\
\hline & Reservoir flushing & & $\checkmark$ & $\checkmark$ & $\checkmark$ \\
\hline \multirow{2}{*}{ Period } & Before spawning period of target fish species & $\checkmark$ & & & \\
\hline & Before peak annual discharge & & $\checkmark$ & $\checkmark$ & $\checkmark$ \\
\hline \multirow{7}{*}{ Frequency } & One / two years & $\checkmark$ & & & $\checkmark$ \\
\hline & Based on constant assessment & $\checkmark$ & $\checkmark$ & $\checkmark$ & $\checkmark$ \\
\hline & $\begin{array}{l}\text { Assessment Methods } \\
\text { Identify relevant assessment methods for defined objectives }\end{array}$ & & & & \\
\hline & Biotic indicators & $\checkmark$ & $\checkmark$ & $\checkmark$ & $\checkmark$ \\
\hline & Abiotic indicators & & $\checkmark$ & $\checkmark$ & $\checkmark$ \\
\hline & Topographic survey & & $\checkmark$ & $\checkmark$ & $\checkmark$ \\
\hline & Bedload tracing & & & & $\checkmark$ \\
\hline
\end{tabular}

To use this table, first, existing restrictions at the target reach are identified from the list of restrictions. Second, the foci of the objectives that are relevant (marked by checkmarks) to all of the selected restrictions are identified. Then, relevant design approaches and assessment methods are similarly identified for the selected set of objectives in the corresponding lists. Relevant links are specified in the following sections.

This conceptual framework includes the following considerations. SAMs can have several objectives at a time. Relevant restrictions, design approaches and assessment 
methods may vary or even contradict. In some cases, a restriction for an SAM, e.g., sediment discontinuities, must eventually be removed by a secondary revitalization measure in order to "unlock" a new objective. The final design should be the result of a careful weighing of the relevant options with a consideration of the interests of all stakeholders.

\section{Restrictions}

The rehabilitation and management objectives of an SAM should depend on the target section of the river and vice versa.

A possible restriction for sediment augmentation is the flow regime. At constant low flow discharge, the stream power is insufficient and unable to mobilize considerable amounts of bedload material if the flow is below the entrainment threshold [61]. Discharge variations shape channel patterns [62]. In river reaches with no recurring morphological discharges, the hydrogeomorphic processes are restricted to a point where channel dynamics are largely impaired (e.g., [6,63,64]).

Sediment discontinuities, such as dams or sediment traps, can restrict or prevent the effectiveness of an SAM that aims at restoring the bedload. Hydropower structures affect the bedload budget in very different ways. Both complete and long-term retention, as well as continuous routing, are possible [65].

To enhance channel dynamics through SAMs, the river corridor and the bank structure need to allow lateral migration. Downstream of dams, the encroachment of alluvial vegetation can stabilize channel banks [66] and lead to the important narrowing of the active channel width [64], especially if there are no recurring floods and the bedload transport rates are sufficient enough to cause the dynamic reshaping of the riparian zone. In populated areas, artificial bank protection for flood protection or channelization equally impairs channel evolution.

The required conditions for a successful SAM can be a limiting factor, or they might otherwise be the target of a secondary rehabilitation measure and used to create possible synergies [65]. For example, where no recurring major morphological discharges limit the enhancement of channel dynamics, the introduction of a regular flushing scheme can be coupled with an SAM. This can provide both the required flow discharge and the necessary transport capacity, not just to progressively enhance channel dynamics, but also to promote the regular shifting and declogging of the riverbed.

\section{Design Approaches}

\subsection{Sediment Properties}

The properties of all types of augmented sediment mixtures should reflect the riverbed material in its natural state. This means that the material should have a relatively low content of fine particles (washed) in order to reduce clogging [13], and it should have an abraded topography, similar to an alluvial material (rolled), in order to promote mobilization [67]. Gravel is usually better for sediment-depleted river systems than fine sediments, which causes colmation of the substratum and high turbidity [68]. Schälchli [69] provides a rough estimation for the diameter of suspended grains that can cause internal colmation $(>0.02 \mathrm{~mm})$ and external colmation $(>1 \mathrm{~mm})$, depending on the filter medium. If a sediment mix is added for other management purposes (e.g., to manage scour issues) or material is supplied from a reservoir or the adjacent floodplain, these properties can vary. If organic material, such as earth or mud, is included, biological clogging [70] or eutrophication [71] can have adverse ecological effects. If the amount of organic input remains low, the adverse effects are negligible compared to the quantities of natural organic matter that are transported during a major flood event [72].

If the principal objective is the creation of new spawning habitats, the grain size distribution (GSD) depends on the target fish species. Usually, the dominant fish species of the region is targeted. The dominant species can typically be identified based on the mean slope and channel width [73]. Diminishing numbers of specific fish stock can lead to the selection of a different target species. Based on a review of 22 publications, it appears that 
the Atlantic salmon (Salmo salar) and brown trout (Salmo trutta) generally prefer pebbles that range from $16 \mathrm{~mm}$ to $64 \mathrm{~mm}$ in diameter for spawning [74]. In some areas, smaller grain sizes of around $20 \mathrm{~mm}$ to $30 \mathrm{~mm}$ are identified as traditional female spawning grounds (e.g., [75]). In addition, a smaller percentage (below $20 \%$ ) of fine particles $(\mathrm{d}<0.85 \mathrm{~mm}$ ) was found to sharply increase the survival rate of fish embryos before their emergence [76]. This can be linked to the fact that the oxygen concentration may be reduced by the deposition of fine sediments [74].

For the alteration of the riverbed structure or channel dynamics, a broader GSD is possible, depending on the desired morphological impact on the target reach. Laboratory experiments have shown that sediment pulses with material finer than the median diameter of the surface layer can promote its mobilization and fining [77]. On the other hand, numerical investigations into the effect of grain size on bed deformation in meandering channels have shown that increasing the GSD of the bed surface (i) increases bedform height, (ii) decreases the bedform length, and (iii) gradually changes the bed configurations over time from the alternate bars shape to the ripple shape [78].

If the principal objective is to target the balancing of the bedload budget, the GSD of the augmented sediments should represent the GSD of the natural bedload material of the river. Bedload, by definition, consists of "particles that spend the majority of the time on the bottom, but are periodically entrained into the turbulent water flow and carried a short distance downstream before settling again" [79]. The boundary between bedload and suspended load is not sharp, and depends on the flow strength, where grains coarser than about $8 \mathrm{~mm}$ tend to travel as bedload [80]. A common conceptualization of bedload motion involves the visualization of an active layer [81], where a distinction has recently been drawn between an event active layer and a dynamical active layer [82]. Both types of mechanism may be targeted by an SAM. Hereon, these mechanisms are correspondingly referred to dynamical active or event active bedload supply. The latter represents the coarser fraction of the bedload material, which is only mobilized during a channel-forming flood event ( HQ2).

\subsection{Volume}

The sediment volume of a single SAM in the case studies varies from small $\left(<10^{3} \mathrm{~m}^{3}\right)$ (e.g., [21,25]) to medium $\left(10^{3}-10^{4} \mathrm{~m}^{3}\right)($ e.g., $[34,43])$ and large $\left(10^{4}-5 \times 10^{4} \mathrm{~m}^{3}\right)($ e.g., $[32,35])$.

The required volume for SHR can be estimated based on the missing spawning substrate that might other potentially be present in the target section. The criteria for identifying potential spawning habitat space varies according to the species and is largely determined by hydraulic factors, such as water depth and flow velocity [83], as well as the morphologic factors, such as spawning pit depth and bed surface structure [84]. Salmon spawn mostly at a flow depth of $20 \mathrm{~cm}$ to $50 \mathrm{~cm}$ and at an average flow velocity of $0.35 \mathrm{~ms}^{-1}$ to $0.65 \mathrm{~ms}^{-1}$, while trout spawning areas were found at slightly shallower sites $(15 \mathrm{~cm}-45 \mathrm{~cm})$ with lower flow velocities $\left(0.2 \mathrm{~ms}^{-1}-0.55 \mathrm{~ms}^{-1}\right)$ [74]. The mean spawning pit depth of the brown trout, adjusted according to channel type and geomorphic unit, was assessed based on 268 randomly sampled pits, and was found to be between $6.6 \mathrm{~cm}$ and $9.4 \mathrm{~cm}$ [84]. This height determines, according to the species, the minimum height of the spawning-suitable substrate that is required at potential spawning ground locations. The typical bed surface structure of the brown trout spawning area is in the upward front slope of a riffle structure [52]. A similar preference of bed surface structure was reported for the Chinook salmon, where most of the spawning $(73 \%)$ occurred upstream of the crest of the riffles [85].

If morphological changes are the principal objectives, the required volume for SAMs can be estimated using hydro-morphological modelling [86-88]. Single, small or mediumsized SAMs have been shown to alter riverbed structures [25,42]. Significant channel shifting, on the other hand, has not been reported, even for large single SAMs [32]. Laboratory experiments suggest that sediment supply has a significant amount of control over channel-scale bedforms [57], especially if the conditions of constant discharge and 
non-erodible banks do not prevail [89]. Channel dynamics are thus likely to be altered significantly only with recurring supplies of sufficient sediment volumes. For the morphological development of dynamic river widenings, a sufficiently large, constant sediment supply is presupposed [55].

Some federal guidelines have lately produced a uniform definition and calculation of bedload budget for sediment regime rehabilitation with SAMs. The French guidelines for the measurement and modelling of bedload transport [90] defines the transport capacity as the temporal mean of the bedload transport rate. The numerical calculation is based on an equilibrium state, supposing a uniform flow and bedload regime and sufficient material at one's disposal. The Swiss guidelines for bedload regime rehabilitation states that the evaluation of the sediment augmentation volume required to balance the bedload budget should be based on a defined reference state that is determined according to the watercourse [65]. Schälchli and Hunzinger [91] defined five major goals (which are concerned with channel shape, sediment deposits, substratum, groundwater regimes and flood protection) that must be met, and provide empirically based evaluation methods for the corresponding bedload volume.

\subsection{Injection Method}

In-channel injection facilitates the instantaneous creation of spawning habitats [92]. Here, sediments are directly dredged out or installed in place to modify the riverbed structure in the target reach (see Figure 3). SHR can be planned with the help of hydrodynamic [31] or ecological modelling [93]. In recent years, artificial riffles have also been constructed to improve water flow and sediment transportation, as well as to initiate the processes that lead to the restoration of natural riffle-pool sequences [94].

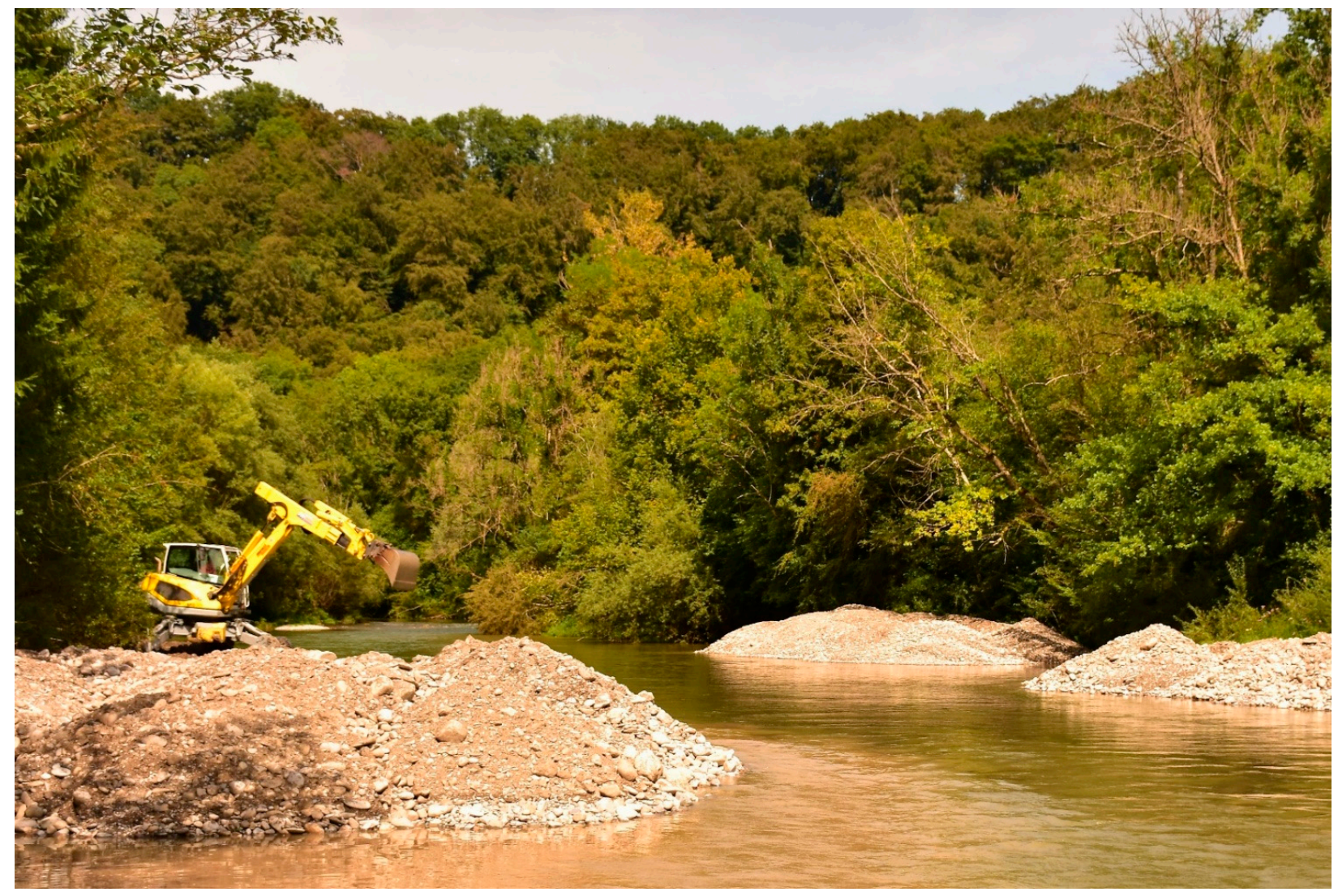

Figure 3. Installation of in-channel stockpiles at the residual flow section of the Sarine River, downstream of Rossens Dam, Switzerland, in 2016. About $1000 \mathrm{~m}^{3}$ of an alluvial sediment mixture from the adjacent floodplain were injected and coupled with an artificial flood to improve the downstream riverbed structure and increase habitat diversity. 
If accessibility, budget or other reasons require an upstream supply of sediment, inchannel, point bar or high-flow stockpiles are common alternatives [47]. Stockpile injection can require supplementary conditions for an SAM that might decrease its efficiency, especially when the principal objective concerns SHR. A mobilization event has to occur before vegetation encroachment stabilizes the stockpiles, and the sediments therefore need to be mobilized and deposited in sufficient quantities at the location of potential spawning sites [27].

To prevent vegetation encroachment from stabilizing the stockpiles, high-flow constant injection, e.g., with a heavy truck or a conveyer belt [24], is another method for sediment supply. Laboratory experiments suggest that a high degree of sediment pulse dispersion occurs with high-flow injection, with only some translational transport behaviour occurring for larger hydrographs that are much greater than the entrainment threshold [95]. Depending on the objective of the SAM, the dispersal behaviour of the sediment pulse might require the adaption of other design criteria, e.g., the volume.

One way of passively supplying sediments to a river is by inducing bank erosion. Rohde et al. [51] describe three different types of measures, namely, self-dynamic development, self-dynamic development with initial measures and mechanical widening. One example is the Töss River in Switzerland, where the flow was divided with an artificial island consisting of large boulders [96]. At the Mur River in Austria, a sidearm was dredged and bank erosion was enabled by the removal of bank protection structures. Coupled with in-channel injection, the short-term success of countering channel incision could be assessed [97]. Since riverbank failure, basal residence time and the supply of material to the in-channel sediment transfer system are coupled processes and difficult to simulate [98], the prediction of the morphological impact of a corresponding SAM entails a high degree of uncertainty.

Sediment augmentation through the reactivation of old side channels can increase sediment transport [40] but it may take decades until a new (quasi)equilibrium of the bedload budget is reached. Under natural boundary conditions, a positive cascading effect on channel dynamics, bedload structure and interstitial habitat may develop (Figure 2).

\subsection{Mobilization Event}

If no direct in-channel injection is to be performed, then an SAM requires flood events to mobilize the injected sediments.

Natural flood events are often difficult to predict and might not occur at the right time or magnitude for SHR. For the remaining principal foci of objectives for SAMs (1-3), single or several natural flood events have been successfully used to mobilize parts of mostly large augmented sediment volumes [32,33]. In Japan, natural floods are expected in monsoon season and can be controlled to favour both reservoir flushing and downstream SAMs [99].

Environmental flow releases from reservoirs target downstream ecological or management objectives [100]. An environmental flow release scheme ideally contains both large channel maintenance floods that would have a morphologic impact, as well as smaller floods for habitat maintenance [101]. Therefore, it can be coupled with all forms of SAMs.

As well as environmental flow releases that benefit the river, reservoir flushing operations also focus on issues inside the reservoir, such as emptying the reservoir of sediments [102]. Even though a synthesis between reservoir flushing operations and downstream rehabilitation measures, such as with SAMs, has been called for [103], the multiple objectives are often too far apart to permit the specification of a particular discharge and water volume [104]. It is therefore assumed that reservoir flushing, as a mobilization event, is a relevant design approach for SAMs with less specific morphological target states. 


\subsection{Period and Frequency}

The period and frequency of SAMs depend on the principal objective. In any case, in-channel construction works should fall outside the flooding season and reproduction seasons of dominant aquatic species.

SAMs for SHR should be implemented before the spawning period of the target fish species so that they can provide clean and unclogged spawning substrates. In Switzerland, the Federal Office of the Environment (FOEN) recommends performing SAMs for SHR from the late summer to the autumn, between the reproduction period of cyprinids and salmonids [105]. Depending on the size of the watercourse, a repetition after one or two years has been proven to be reasonable for maintaining the positive effects on the fish fauna [52].

Changing the riverbed or channel structure with an upstream sediment supply requires major mobilization events [32,34]. The SAM should therefore seek to benefit from peak annual discharge and be repeated based on recurrent assessment.

Bedload restoration with SAMs should be optimized in a way that ensures that bedload is regularly available for transport. The discharge years and discharge quantities can also be flexibly determined depending on the available bedload so that the required bedload is eventually deposited over time.

\section{Assessment Methods}

Different types of assessment methods exist to quantify the effectiveness of SAMs. The assessment methods should be defined in the early planning stage and be based on the dimension, effort and objective of the SAM, as well as on the ecological importance of the watercourse.

Biotic indicators, such as communities of fish [106,107], benthic macroinvertebrate [108] or riparian vegetation [109], as well as suspended particle organic matter [58], have been used to investigate the effects of SAMs. The selection of biotic indicators varies according to location and should be proven to show a measurable and quantifiable relationship with broader biodiversity [110]. Under this condition, biotic indicators can be used for shortand long-term assessment for all types of SAMs.

Abiotic indicators are based on the field records of hydro-morphological parameters. For example, the Hydro-Morphological Index of Diversity (HMID) [41] is calculated from the records of flow velocity and water depth along predefined transects, and provides a quantification measure for the degree of flow complexity and morphological variability. It has been used to assess changes in the riverbed structure after an SAM [111,112] and to assess the development of channel dynamics [59] (Figure 4a). Abiotic indicators can also indirectly provide insights into the effectiveness of sediment augmentation for bedload regime rehabilitation, e.g., through the assessment of the degree of colmation in the downstream reach [113] (Figure 4b).

Topographic surveys using satellites, aerial imagery or bathymetry can be used to assess morphodynamic development after the implementation of an SAM on a reach- [34] and basin-scale [37]. These methods are suited for large-scale and long-term impact assessment at reduced costs, due to the typically high degree of automatization in the data acquisition and processing procedures.

SAMs that focus on bedload regime rehabilitation can also be assessed based on bedload measurements. Direct measurement of bedload is performed with specially designed sediment traps [2]. For indirect, continuous measurements, acoustic instruments, including geophones, hydrophones and underwater microphones [114], as well as acoustic Doppler current profilers [115], can be used. Passive measurements have also been performed in recent years using more sensitive seismic measurements [116]. Another indirect measurement, successfully used to assess the impact of an SAM, is RFID-pit tracing [33]. Sediments are marked with a tracer, placed inside the sediment augmentation deposit and are later searched for with the help of a mobile antenna [42] (Figure 4c-e). 

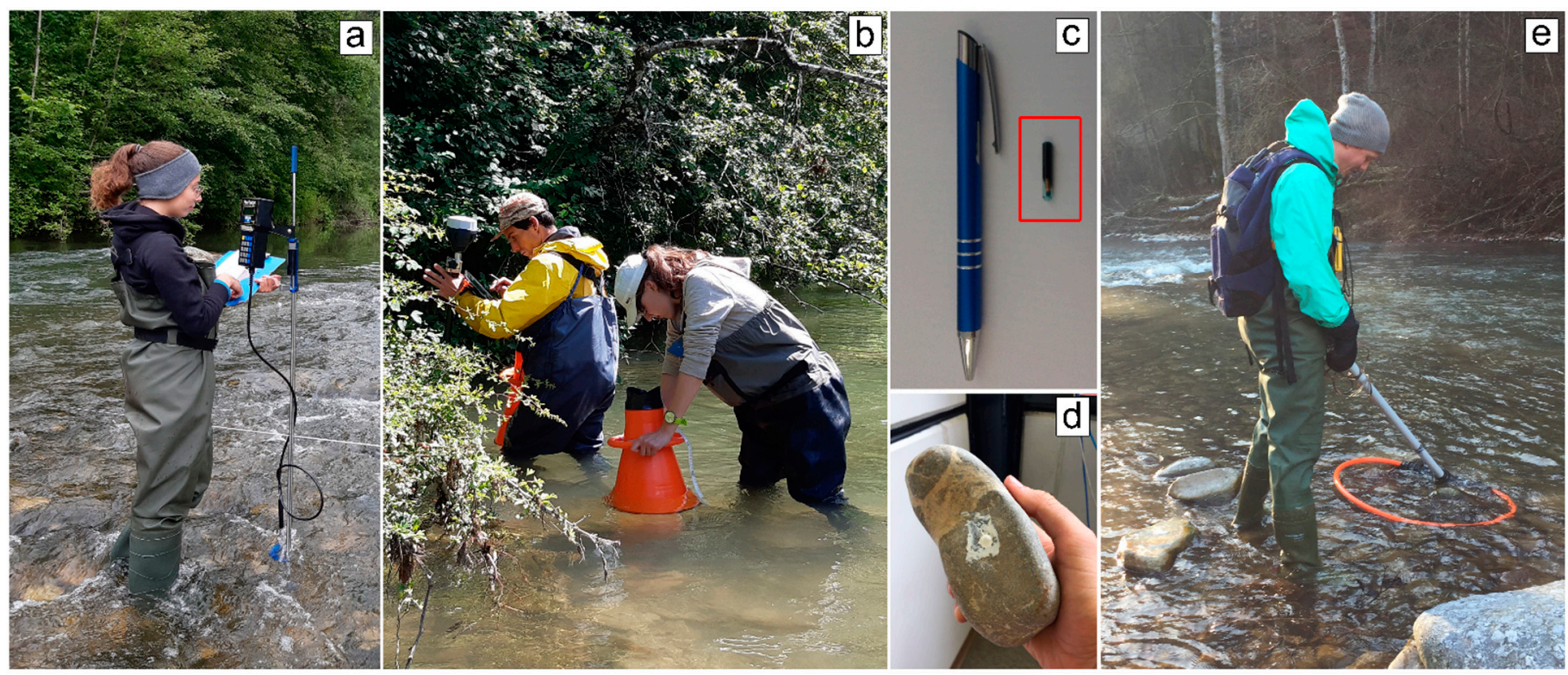

Figure 4. Assessment of the eco-morphological effectiveness of a sediment augmentation measure: (a) recording flow velocities and water depth along fixed cross-sections, for the calculation of the HMID abiotic indicator; (b) mapping substrate quality for the calculation of the IRS [113] abiotic indicator; (c) RFID-pit sensor; (d) a pebble with an RFID-pit sensor inside; (e) post-flood bedload tracing, searching for RFID-pit sensor pebble with a mobile antenna.

In any case, the selection of assessment methods and the defined indicators, as well as the interpretation of their development after project implementation, must be conducted after careful consideration. Woolsey et al. [117] suggest four guidelines for the projectspecific indicator selection for river restoration projects. They recommend: (i) limiting the number of indicators, which together represent all project objectives; (ii) the use of direct indicators rather than indirect ones; (iii) choosing indicators that require low effort, especially where financial and time constraints are important; and (iv) the selection of survey intervals that represent both the interannual patterns and the years that elapse after restoration. In addition, for a more holistic ecological approach, the combination of different assessment methods and indicators can lead to a better representation of the interaction of communities of species and habitat properties [118].

\section{Conclusions}

In this paper, objective-focused restrictions, design criteria, and assessment methods for sediment augmentation measures (SAMs) are presented. They are based on a comparison of a selection of case studies from the USA, Japan, and Europe, related publications, and our own experience from working in the field.

A conceptual framework for the objective-focused design of SAMs is introduced, where different measures are grouped by the focus of their principal rehabilitation and management objectives, including (1) bedload budget, (2) channel dynamics, (3) riverbed structure, and (4) interstitial (spawning) habitat. For every objective, existing knowledge from the literature is summarized and set into the context of objective-focused SAMs to provide practical design information for river rehabilitation and management. Literature from hydraulic, morphological, and ecological research is combined and synthesized based on the authors' experience from the design [42] and assessment [113] of the 2016 Sarine River SAM.

The selection of case studies from three different regions, where the most quantitative and diverse examples were scientifically documented, contributes to a reliable and representative base of reference projects. However, the knowledge presented in this review does not consider experience from numerous unpublished SAMs or scientific surveys on SAMs outside the selected regions. 
Beyond empirically or numerically based predictions, successful planning and implementation of SAMs still requires a great amount of experience from the field and good engineering judgement.

Author Contributions: Investigation, conceptualization, and writing-original draft preparation, C.M.; Funding acquisition, project administration, supervision and writing—review and editing, G.D.C. All authors have read and agreed to the published version of the manuscript.

Funding: This research was conducted within the framework of the River Engineering and Ecology project, funded by the Swiss Federal Office of the Environment (FOEN): 16.0113.PJ / S033-1283.

Conflicts of Interest: The authors declare no conflict of interest. The funders had no role in the design of the study; in the collection, analyses, or interpretation of data; in the writing of the manuscript, or in the decision to publish the results.

\section{Appendix A}

Table A1. Data and source of scatter plot Figure 1.

\begin{tabular}{|c|c|c|c|c|c|c|}
\hline Region & Location & Year & $\begin{array}{c}\text { Volume of } \\
\text { Effective } \\
\text { Sediment } \\
\text { Augmentation } \\
\left(\mathrm{m}^{3}\right)\end{array}$ & $\begin{array}{c}\text { Average Grain } \\
\text { Diameter }\left(\mathrm{d}_{50}\right) \\
\text { of Sediment } \\
\text { Augmentation } \\
(\mathrm{mm})\end{array}$ & $\begin{array}{c}\text { Peak } \\
\text { Discharge of } \\
\text { First Flow } \\
\text { Event }\left(\mathrm{m}^{3} / \mathrm{s}\right)\end{array}$ & $\begin{array}{l}\text { Case } \\
\text { Study }\end{array}$ \\
\hline \multirow{3}{*}{ Japan } & $\begin{array}{l}\text { Nunome River downstream of } \\
\text { Nunome Dam }\end{array}$ & 2008 & 100 & 0.38 & 15.36 & [19] \\
\hline & $\begin{array}{l}\text { Nunome River downstream of } \\
\text { Nunome Dam }\end{array}$ & 2009 & 500 & 0.38 & 81.01 & [19] \\
\hline & $\begin{array}{l}\text { Uda River downstream of } \\
\text { Murou Dam }\end{array}$ & 2009 & 230 & 1.25 & 13 & [21] \\
\hline \multirow{3}{*}{ USA } & $\begin{array}{l}\text { Trinity River downstream of } \\
\text { Lewiston Dam }\end{array}$ & 2010 & 1170 & 40 & 184 & [24] \\
\hline & $\begin{array}{l}\text { Trinity River downstream of } \\
\text { Lewiston Dam }\end{array}$ & 2011 & 1570 & 40 & 311 & [24] \\
\hline & $\begin{array}{l}\text { Trinity River downstream of } \\
\text { Lewiston Dam }\end{array}$ & 2015 & 520 & 64 & 245 & [25] \\
\hline \multirow{3}{*}{ Europe } & $\begin{array}{l}\text { Rhine River downstream of } \\
\text { the Kembs Dam }\end{array}$ & 2012 & 11,500 & 37 & 1340 & [33] \\
\hline & $\begin{array}{c}\text { Sarine River downstream of } \\
\text { Rossens Dam }\end{array}$ & 2016 & 500 & 39 & 195 & [42] \\
\hline & $\begin{array}{l}\text { Buëch River downstream of } \\
\text { Saint-Sauveur Dam }\end{array}$ & 2016 & 22,650 & 33 & 265 & [32] \\
\hline
\end{tabular}

\section{References}

1. Wohl, E.; Bledsoe, B.P.; Jacobson, R.B.; Poff, N.L.; Rathburn, S.L.; Walters, D.M.; Wilcox, A.C. The natural sediment regime in Rivers: Broadening the foundation for ecosystem management. Bioscience 2015, 65, 358-371. [CrossRef]

2. Yang, S.L.; Zhang, J.; Xu, X.J. Influence of the three gorges dam on downstream delivery of sediment and its environmental implications, Yangtze river. Geophys. Res. Lett. 2007, 34, L10401. [CrossRef]

3. Habersack, H.; Piégay, H. River restoration in the Alps and their surroundings: Past experience and future challenges. Dev. Earth Surf. Process. 2007, 11, 703-735.

4. Ward, J.V.; Stanford, J.A. Ecosystems and Its disruption by flow regulation. Regul. Rivers Res. Manag. 1995, 2, 105-119. [CrossRef]

5. Draut, A.E.; Logan, J.B.; Mastin, M.C. Channel evolution on the dammed Elwha river, Washington, USA. Geomorphology 2011, 127, 71-87. [CrossRef]

6. Kondolf, G.M. Hungry water: Effects of dams and gravel mining on river channels. Environ. Manag. 1997, 21, 533-551. [CrossRef]

7. Rollet, A.J.; Piégay, H.; Dufour, S.; Bornette, G.; Persat, H. Assessment of consequences of sediment deficit on a Gravel river bed downstream of dams in restoration perspectives: Application of a multicriteria, hierarchical and spatially explicit diagnosis. River Res. Appl. 2014, 30, 939-953. [CrossRef]

8. Rinaldi, M.; Casagli, N. Stability of streambanks Formed in partially saturated soils and effects of negative pore water pressures: The Sieve river (Italy). Geomorphology 1999, 26, 253-277. [CrossRef] 
9. White, W.R. Sediments in the freshwater environment. Rev. Curr. Knowl 2015, FR/R0022.

10. Batalla Villanueva, R. Sediment deficit in rivers caused by dams and instream gravel mining: A review with examples from NE Spain. Cuaternario y Geomorfología 2003, 17, 79-91.

11. Hauer, C.; Unfer, G.; Helmut, H.; Pulg, U.; Schnell, J. Bedeutung von flussmorphologie und sedimenttransport in Bezug auf die qualität und nachhaltigkeit von Kieslaichplätzen. Korresp. Wasserwirtsch. 2013, 6, 189-197. [CrossRef]

12. Sato, T.; Kano, Y.; Huang, L.; Yamashita, T.; Li, J.; Shimatani, Y. Relationships between fish richness, habitat diversity, and channel parameters in gravel-bed streams in the East Tiaoxi Riv. In Proceedings of the 11th ISE 2016, Melbourne, Australia, 7-12 February 2016.

13. Schälchli, U. The clogging of coarse gravel river beds by fine sediment. Hydrobiologia 1992, 235-236, 189-197. [CrossRef]

14. Brunke, M. Colmation and depth filtration within streambeds: Retention of particles in hyporheic interstices. Int. Rev. Hydrobiol. 1999, 84, 99-117. [CrossRef]

15. Graf, W.; Leitner, P.; Hanetseder, I.; Ittner, L.D.; Dossi, F.; Hauer, C. Ecological degradation of a meandering river by local channelization effects: A case study in an Austrian Lowland river. Hydrobiologia 2016, 772, 145-160. [CrossRef]

16. Kondolf, G.M.; Gao, Y.; Annandale, G.W.; Morris, G.L.; Jiang, E.; Zhang, J.; Cao, Y.; Carling, P.; Fu, K.; Guo, Q.; et al. Sustainable sediment management in reservoirs and regulated rivers: Experiences from five continents. Earth's Futur. 2014, 2, 256-280. [CrossRef]

17. Sumi, T.; Kantoush, S.; Esmaeili, T.; Ock, G. Reservoir sediment flushing and replenishment below dams. In Gravel-Bed Rivers; Tsutsumi, D., Laronne, J.B., Eds.; John Wiley \& Sons, Ltd.: Chichester, UK, 2017; pp. 385-414.

18. Sumi, T.; Kantoush, S. Sediment management strategies for sustainable reservoir. In Dams and Reservoirs under Changing Challenges; Schleiss, A.J., Boes, R.M., Eds.; Taylor \& Francis Group: London, UK, 2011; pp. 353-362. ISBN 9780415682671.

19. Kantoush, S.A.; Sumi, T.; Kubota, A. Geomorphic response of rivers below dams by sediment replenishment technique. In Proceedings of the River Flow 2010 Conference, Braunschweig, Germany, 8-10 September 2010; Dittrich, A., Koll, K., Aberle, J., Geisenhainer, P., Eds.; pp. 1155-1163.

20. Ock, G.; Kondolf, G.M.; Takemon, Y.; Sumi, T. Missing link of coarse sediment augmentation to ecological functions in regulated rivers below dams: Comparative approach in Nunome River, Japan and Trinity River, California, US. In Advances in River Sediment Research; Fukuoka, S., Nakagawa, H., Sumi, T., Zhang, H., Eds.; Taylor \& Francis Group: London, UK, 2013 ; ISBN 9780429227783.

21. Kantoush, S.A.; Sumi, T. Sediment replenishing measures for revitalization of Japanese rivers below dams. In Proceedings of the 34th IAHR World Congress, Brisbane, Australia, 26 June-1 July 2011; pp. 2838-2846.

22. Bunte, K. Gravel Mitigation and Augmentation below Hydroelectric Dams: A Geomorphological Perspective; Colorado State University: Fort Collins, CO, USA, 2004. [CrossRef]

23. Kondolf, G.M.; Wolman, M.G. The sizes of salmonid spawning gravels. Water Resour. Res. 1993, 29, 2275-2285. [CrossRef]

24. Gaeuman, D. High-flow gravel injection for constructing designed in-channel features. River Res. Appl. 2014, 30, 685-706. [CrossRef]

25. Gaeuman, D.; Stewart, R.; Schmandt, B.; Pryor, C. Geomorphic response to gravel augmentation and high-flow dam release in the Trinity river, California. Earth Surf. Process. Landf. 2017, 42, 2523-2540. [CrossRef]

26. Wheaton, J.M.; Pasternack, G.B.; Merz, J.E. Spawning habitat rehabilitation-II. Using hypothesis development and testing in design, Mokelumne river, California, USA. Int. J. River Basin Manag. 2004, 2, 21-37. [CrossRef]

27. Wheaton, J.M.; Pasternack, G.B.; Merz, J.E. Spawning habitat rehabilitation-I. Conceptual approach and methods. Int. J. River Basin Manag. 2004, 2, 3-20. [CrossRef]

28. Zeug, S.C.; Sellheim, K.; Watry, C.; Rook, B.; Hannon, J.; Zimmerman, J.; Cox, D.; Merz, J. Gravel augmentation increases spawning utilization by anadromous salmonids: A case study from California, USA. River Res. Appl. 2014, 30, 707-718. [CrossRef]

29. Sellheim, K.L.; Watry, C.B.; Rook, B.; Zeug, S.C.; Hannon, J.; Zimmerman, J.; Dove, K.; Merz, J.E. Juvenile salmonid utilization of floodplain rearing habitat after gravel augmentation in a regulated river. River Res. Appl. 2016, 32, 610-621. [CrossRef]

30. Merz, J.E.; Ochikubo Chan, L.K. Effects of gravel augmentation on macroinvertebrate assemblages in a regulated California river. River Res. Appl. 2005, 21, 61-74. [CrossRef]

31. Cepello, S.; Kennedy, S.; Manwaring, M.; Pasternack, G.B. Spawning riffle gravel supplementation for Anadromous Spring-Run Chinook Salmon and Steelhead. In Proceedings of the Waterpower XVI, Spokane, WA, USA, 27-30 July 2009; pp. 1-18.

32. Brousse, G.; Arnaud-Fassetta, G.; Liébault, F.; Bertrand, M.; Melun, G.; Loire, R.; Malavoi, J.; Fantino, G.; Borgniet, L. Channel response to sediment replenishment in a large gravel-bed river: The case of the Saint-Sauveur dam in the Buëch river (Southern Alps, France). River Res. Appl. 2020, 36, 880-893. [CrossRef]

33. Arnaud, F.; Piégay, H.; Béal, D.; Collery, P.; Vaudor, L.; Rollet, A.-J. Monitoring gravel augmentation in a Large regulated river and implications for process-based restoration. Earth Surf. Process. Landf. 2017, 42, 2147-2166. [CrossRef]

34. Heckmann, T.; Haas, F.; Abel, J.; Rimböck, A.; Becht, M. Feeding the hungry river: Fluvial morphodynamics and the entrainment of artificially inserted sediment at the dammed river Isar, Eastern Alps, Germany. Geomorphology 2017, 291, 128-142. [CrossRef]

35. Chardon, V.; Schmitt, L.; Arnaud, F.; Piégay, H.; Clutier, A. Efficiency and sustainability of gravel augmentation to restore large regulated rivers: Insights from three experiments on the Rhine river (France/Germany). Geomorphology 2021, $380,107639$. [CrossRef] 
36. Staentzel, C.; Arnaud, F.; Combroux, I.; Schmitt, L.; Trémolières, M.; Grac, C.; Piégay, H.; Barillier, A.; Chardon, V.; Beisel, J.-N. How do instream flow increase and gravel augmentation impact biological communities in large rivers: A case study on the Upper Rhine river. River Res. Appl. 2018, 34, 153-164. [CrossRef]

37. Frings, R.M.; Hillebrand, G.; Gehres, N.; Banhold, K.; Schriever, S.; Hoffmann, T. From source to mouth: Basin-scale morphodynamics of the Rhine river. Earth Sci. Rev. 2019, 196, 102830. [CrossRef]

38. Frings, R.M.; Döring, R.; Beckhausen, C.; Schüttrumpf, H.; Vollmer, S. Fluvial sediment budget of a modern, restrained river: The lower reach of the Rhine in Germany. Catena 2014, 122, 91-102. [CrossRef]

39. Marteau, B.; Gibbins, C.; Vericat, D.; Batalla, R.J. Geomorphological response to system-scale river rehabilitation I: Sediment supply from a reconnected tributary. River Res. Appl. 2020, 36, 1488-1503. [CrossRef]

40. Marteau, B.; Gibbins, C.; Vericat, D.; Batalla, R.J. Geomorphological response to system-scale river rehabilitation II: Main-stem channel adjustments following reconnection of an Ephemeral tributary. River Res. Appl. 2020, 36, 1472-1487. [CrossRef]

41. Gostner, W.; Alp, M.; Schleiss, A.J.; Robinson, C.T. The Hydro-Morphological Index of Diversity: A tool for describing habitat heterogeneity in river engineering projects. Hydrobiologia 2013, 712, 43-60. [CrossRef]

42. Stähly, S.; Franca, M.J.; Robinson, C.T.; Schleiss, A.J. Sediment replenishment combined with an artificial flood improves river habitats downstream of a dam. Sci. Rep. 2019, 9, 1-7. [CrossRef]

43. Stähly, S.; Franca, M.J.; Robinson, C.T.; Schleiss, A.J. Erosion, transport and deposition of a sediment replenishment under flood conditions. Earth Surf. Process. Landf. 2020, 45, 3354-3367. [CrossRef]

44. Bertrand, M.; Piégay, H.; Pont, D.; Liébault, F.; Sauquet, E. Sensitivity analysis of environmental changes associated with riverscape evolutions following sediment reintroduction: Geomatic approach on the Drôme river network, France. Int. J. River Basin Manag. 2013, 11, 19-32. [CrossRef]

45. Staentzel, C.; Kondolf, G.M.; Schmitt, L.; Combroux, I.; Barillier, A.; Beisel, J.N. Restoring fluvial forms and processes by gravel augmentation or bank erosion below dams: A systematic review of ecological responses. Sci. Total Environ. 2020, 706, 135743. [CrossRef] [PubMed]

46. Mizuyama, T.; Laronne, J.; Nonaka, M.; Sawada, T.; Satofuka, Y.; Matsuoka, M.; Yamashita, S.; Sako, Y.; Tamaki, S.; Watari, M.; et al. Calibration of a passive acoustic bedload monitoring system in Japanese mountain rivers. US Geol. Surv. Sci. Investig. Rep. 2010, 5091, 296-318.

47. Ock, G.; Sumi, T.; Takemon, Y. Sediment replenishment to downstream reaches below dams: Implementation perspectives. Hydrol. Res. Lett. 2013, 7, 54-59. [CrossRef]

48. Hillman, M.; Brierley, G. A critical review of catchment-scale stream rehabilitation programmes. Prog. Phys. Geogr. Earth Environ. 2005, 29, 50-76. [CrossRef]

49. Benke, A.C. Importance of flood regime to invertebrate habitat in an unregulated river-floodplain ecosystem. J. North Am. Benthol. Soc. 2001, 20, 225-240. [CrossRef]

50. Scheurer, T.; Molinari, P. Experimental floods in the river Spöl, Swiss national park: Framework, objectives and design. Aquat. Sci. 2003, 65, 183-190. [CrossRef]

51. Rohde, S.; Schütz, M.; Kienast, F.; Englmaier, P. River widening: An approach to restoring riparian habitats and plant species. River Res. Appl. 2005, 21, 1075-1094. [CrossRef]

52. Pulg, U.; Barlaup, B.T.; Sternecker, K.; Trepl, L.; Unfer, G. Restoration of spawning habitats of Brown Trout (Salmo Trutta) in a regulated chalk stream. River Res. Appl. 2013, 29, 172-182. [CrossRef]

53. Pfeiffer, A.M.; Finnegan, N.J.; Willenbring, J.K. Sediment supply controls equilibrium channel geometry in gravel rivers. Proc. Natl. Acad. Sci. USA 2017, 114, 3346-3351. [CrossRef] [PubMed]

54. Frings, R.M.; Gehres, N.; Promny, M.; Middelkoop, H.; Schüttrumpf, H.; Vollmer, S. Today's sediment budget of the Rhine river channel, focusing on the upper Rhine Graben and Rhenish Massif. Geomorphology 2014, 204, 573-587. [CrossRef]

55. Rachelly, C.; Weitbrecht, V.; Vetsch, D.F.; Boes, R.M. Morphological development of river widenings with variable sediment supply. E3S Web Conf. 2018, 40, 02007. [CrossRef]

56. Eaton, B.C.; Church, M. A graded stream response relation for bed load-dominated streams. J. Geophys. Res. 2004, 109 , F03011. [CrossRef]

57. Venditti, J.G.; Nelson, P.A.; Minear, J.T.; Wooster, J.; Dietrich, W.E. Alternate bar response to sediment supply termination. J. Geophys. Res. Earth Surf. 2012, 117, 1-18. [CrossRef]

58. Ock, G.; Gaeuman, D.; McSloy, J.; Kondolf, G.M. Ecological functions of restored gravel bars, the Trinity river, California. Ecol Eng. 2015, 83, 49-60. [CrossRef]

59. Harrison, L.R.; Legleiter, C.J.; Wydzga, M.A.; Dunne, T. Channel dynamics and habitat development in a meandering, gravel bed river. Water Resour. Res. 2011, 47, 1-21. [CrossRef]

60. Miwa, H.; Parker, G. Effects of sand content on initial gravel motion in gravel-bed rivers. Earth Surf. Process. Landf. 2017, 42, 1355-1364. [CrossRef]

61. Gintz, D.; Hassan, M.A.; Schmidt, K.-H. Frequency and magnitude of bedload transport in a mountain river. Earth Surf. Process. Landf. 1996, 21, 433-445. [CrossRef]

62. Leopold, L.B.; Wolman, M.G. River channel patterns-Braided, meandering and straight. Prof. Geogr. 1957, 9, 39-85.

63. Sear, D.A. Morphological and sedimentological changes in a gravel-bed river Following 12 years of flow regulation for hydropower. Regul. Rivers Res. Manag. 1995, 10, 247-264. [CrossRef] 
64. Tonolla, D.; Geilhausen, M.; Doering, M. Seven decades of hydrogeomorphological changes in a near-natural (Sense river) and a hydropower-regulated (Sarine river) pre-Alpine river floodplain in Western Switzerland. Earth Surf. Process. Landf. 2021, 46, 252-266. [CrossRef]

65. Schälchli, U.; Kirchhofer, A. Sanierung Geschiebehaushalt-Strategische Planung. Ein Modul der Vollzugshilfe Renaturierung der Gewässer [Reactivation of bedload dynamics-Strategic planning. A Module of the implementation guide for the revitalisation of water bodies.]. Umwelt-Vollzug 2012, 1226.

66. Wilcock, P.R.; Kondolf, G.M.; Matthews, W.V.G.; Barta, A.F. Specification of sediment maintenance flows for a large gravel-bed river. Water Resour. Res. 1996, 32, 2911-2921. [CrossRef]

67. Staudt, F.; Mullarney, J.C.; Pilditch, C.A.; Huhn, K. Effects of grain-size distribution and shape on sediment bed stability, near-bed flow and bed microstructure. Earth Surf. Process. Landforms 2019, 44, 1100-1116. [CrossRef]

68. Hartmann, S. Sustainable Sediment Management of Alpine Reservoirs Considering Ecological and Economical Aspects; Hartmann, S., Knoblauch, H., De Cesare, G., Steinich, C., Eds.; Institut für Wasserwesen Universität der Bundeswehr München: Neubiberg, Germany, 2009; Volume 7, ISBN 1862-9636.

69. Schälchli, U. Die Kolmation von Fliessgewassersohlen: Prozesse Und Berechnungsgrundlagen; ETH: Zürich, Switzerland, 1993.

70. Newcomer, M.E.; Hubbard, S.S.; Fleckenstein, J.H.; Maier, U.; Schmidt, C.; Thullner, M.; Ulrich, C.; Flipo, N.; Rubin, Y. Simulating bioclogging effects on dynamic riverbed permeability and infiltration. Water Resour. Res. 2016, 52, 2883-2900. [CrossRef]

71. Hilton, J.; O'Hare, M.; Bowes, M.J.; Jones, J.I. How green is my river? A new paradigm of eutrophication in rivers. Sci. Total Environ. 2006, 365, 66-83. [CrossRef]

72. Fuller, R.L.; Dennison, J.; Doyle, S.; Levy, L.; Owen, J.; Shope, E.; Swarr, G.; Vo, L.; Weichert, K.; DiCesare, E.; et al. Influence of flood history and hydrology on transport of organic matter in a frequently flooded river. J. Freshw. Ecol. 2014, $29,37-51$. [CrossRef]

73. Huet, M. Aperçu des relations entre la pente et les populations piscicoles des eaux courantes. Schweizerische Zeitschrift für Hydrol. 1949, 11, 332-351. [CrossRef]

74. Louhi, P.; Mäki-Petäys, A.; Erkinaro, J. Spawning habitat of Atlantic Salmon and Brown Trout: General criteria and intragravel factors. River Res. Appl. 2008, 24, 330-339. [CrossRef]

75. Crisp, D.T.; Carling, P.A. Observations on siting, dimensions and structure of salmonid redds. J. Fish Biol. 1989, 34, 119-134. [CrossRef]

76. Chapman, D.W. Critical review of variables used to define effects of fines in redds of large salmonids. Trans. Am. Fish. Soc. 1988, 117, 1-21. [CrossRef]

77. Venditti, J.G.; Dietrich, W.E.; Nelson, P.A.; Wydzga, M.A.; Fadde, J.; Sklar, L. Mobilization of coarse surface layers in gravel-bedded rivers by finer gravel bed load. Water Resour. Res. 2010, 46, 1-10. [CrossRef]

78. Eizel-Din, M.; Bui, M.D.; El Tahawy, T.; Rutschmann, P. Numerical investigation of grain size effect on bed deformation in meandering channel. In Proceedings of the First European IAHR, Edinburgh, UK, 4-6 May 2010.

79. Hemond, H.F.; Fechner, E.J. Chapter 2-Surface Waters. In Chemical Fate and Transport in the Environment; Hemond, H.F., Fechner, E.J., Eds.; Elsevier: Amsterdam, The Netherlands, 2015; pp. 75-218. ISBN 9780123982568.

80. Wilcock, P.R.; Pitlick, J.; Cui, Y. Sediment Transport Primer-Estimating Bed-Material Transport in Gravel-Bed Rivers; General Technical Report by United States Departement of Agriculture: Fort Collins, CO, USA, 2009.

81. du Boys, M.P. Études du régime du rhone et l'action exercée par les eaux sur un lit a fond de graviers indéfiniment affouiable. Ann. Ponts Chaussees 1879, 5, 141-195.

82. Church, M.; Haschenburger, J.K. What is the "Active Layer"? Water Resour. Res. 2017, 53, 5-10. [CrossRef]

83. Lamouroux, N.; Olivier, J.-M.; Persat, H.; PouilLy, M.; Souchon, Y.; Statzner, B. Predicting community characteristics from habitat conditions: Fluvial fish and hydraulics. Freshw. Biol. 1999, 42, 275-299. [CrossRef]

84. Zimmer, M.P.; Power, M. Brown Trout spawning habitat selection preferences and redd characteristics in the Credit river, Ontario. J. Fish Biol. 2006, 68, 1333-1346. [CrossRef]

85. Mesick, C. Studies of spawning habitat for fall-run Chinook Salmon in the Stanislaus river between Goodwin dam and Riverbank from 1994 to 1997. Fish Bull. 2001, 2, 217-252.

86. Juez, C.; Battisacco, E.; Schleiss, A.J.; Franca, M.J. Assessment of the performance of numerical modeling in reproducing a replenishment of sediments in a water-worked channel. Adv. Water Resour. 2016, 92, 10-22. [CrossRef]

87. Vonwiller, L. Numerical Modeling of Morphological Response of Gravel-Bed Rivers to Sediment Supply; ETH: Zurich, Swizerland, 2017.

88. Vonwiller, L.; Vetsch, D.; Boes, R. Modeling streambank and artificial gravel deposit erosion for sediment replenishment. Water 2018, 10, 508. [CrossRef]

89. Nelson, P.A.; Brew, A.K.; Morgan, J.A. Morphodynamic response of a variable-width channel to changes in sediment supply. Water Resour. Res. 2015, 51, 5717-5734. [CrossRef]

90. Camenen, B.; Melun, G. Guide Pour La Mesure et La Modélisation Du Transport Solide [Guide for Measuring and Modeling Solid Transport]. 2021. Available online: https:/ / www.aramis.admin.ch/Default?DocumentID=49806\&Load=true (accessed on 20 November 2021).

91. Schälchli, U.; Hunzinger, L. Die Erforderliche Geschiebefracht [The Required Bedload Volume], Zürich, Switzerland. 2018. Available online: https:/ / docplayer.org/196774927-Die-erforderliche-geschiebefracht.html (accessed on 20 November 2021). 
92. Schwindt, S.; Pasternack, G.B.; Bratovich, P.M.; Rabone, G.; Simodynes, D. Hydro-morphological parameters generate lifespan maps for stream restoration management. J. Environ. Manag. 2019, 232, 475-489. [CrossRef]

93. Schwindt, S.; Pasternack, G.B. Automating flood-safe ecological river modelling and design. In Riverflow 2020; Uijttewaal, W., Franca, M.J., Valero, D., Chavarrias, V., Arbós, C.Y., Schielen, R., Crosato, A., Eds.; Taylor \& Francis Group: London, UK, 2020; ISBN 978-0-367-62773-7.

94. Korpak, J.; Łapuszek, M.; Lenar-Matyas, A.; Maczałowski, A. Effect of riffle sequences on discharge and sediment transport in a mountain stream. J. Ecol. Eng. 2019, 20, 157-166. [CrossRef]

95. Humphries, R.; Venditti, J.G.; Sklar, L.S.; Wooster, J.K. Experimental evidence for the effect of hydrographs on sediment pulse dynamics in gravel-bedded rivers. Water Resour. Res. 2012, 48, 1-15. [CrossRef]

96. Friedl, F. Laboratory Experiments on Sediment Replenishment in Gravel-Bed Rivers; ETH: Zurich, Switzerland, 2017.

97. Klösch, M.; Hornich, R.; Baumann, N.; Puchner, G.; Habersack, H. Mitigating channel incision via sediment input and selfinitiated riverbank erosion at the Mur river, Austria. In Geophysical Monograph Series; Simon, A., Bennett, S.J., Castro, J.M., Eds.; American Geophysical Union: Washington, DC, USA, 2011; Volume 194, pp. 319-336. ISBN 9780875904832.

98. Darby, S.E.; Rinaldi, M.; Dapporto, S. Coupled simulations of fluvial erosion and mass wasting for cohesive river banks. J. Geophys. Res. 2007, 112, F03022. [CrossRef]

99. Kantoush, S.A.; Sumi, T. River morphology and sediment management strategies for sustainable reservoir in Japan and European Alps. Ann. Disas. Prev. Res. Inst. Kyoto Univ. 2010, 53, 821-839.

100. King, J.; Brown, C.; Sabet, H. A scenario-based holistic approach to environmental flow assessments for rivers. River Res. Appl. 2003, 19, 619-639. [CrossRef]

101. Acreman, M.C.; Ferguson, A.J.D. Environmental flows and the European water framework directive. Freshw. Biol. 2010, 55, 32-48. [CrossRef]

102. Schleiss, A.J.; Franca, M.J.; Juez, C.; De Cesare, G. Reservoir sedimentation. J. Hydraul. Res. 2016, 54, 595-614. [CrossRef]

103. Mörtl, C.; Vorlet, S.L.; Manso, P.A.; De Cesare, G. The sediment challenge of Swiss river corridors interrupted by man-made reservoirs. In Riverflow 2020; Uijttewaal, W., Franca, M.J., Valero, D., Chavarrias, V., Arbós, C.Y., Schielen, R., Crosato, A., Eds.; Taylor \& Francis Group: London, UK, 2020; pp. 1764-1773. ISBN 978-0-367-62773-7.

104. Kondolf, G.M.; Wilcock, P.R. The flushing flow problem: Defining and evaluating objectives. Water Resour. Res. 1996, 32, 2589-2599. [CrossRef]

105. Breitenstein, M.; Kirchhofer, A. Förderung der litho-rheophilen fischarten der Schweiz [Promotion of Litho-Rheophilic Fish Species of Switzerland]. 2010. Available online: http:/ / docplayer.org/79536921-Foerderung-der-litho-rheophilen-fischarten-derschweiz.html (accessed on 20 November 2021).

106. Grimardias, D.; Guillard, J.; Cattanéo, F. Drawdown flushing of a hydroelectric reservoir on the Rhône river: Impacts on the fish community and implications for the sediment management. J. Environ. Manag. 2017, 197, 239-249. [CrossRef]

107. Reckendorfer, W.; Badura, H.; Schütz, C. Drawdown flushing in a chain of reservoirs—Effects on Grayling populations and implications for sediment management. Ecol. Evol. 2019, 9, 1437-1451. [CrossRef]

108. Espa, P.; Brignoli, M.L.; Crosa, G.; Gentili, G.; Quadroni, S. Controlled sediment flushing at the Cancano reservoir (Italian Alps): Management of the operation and downstream environmental impact. J. Environ. Manag. 2016, 182, 1-12. [CrossRef]

109. Pasquale, N.; Perona, P.; Schneider, P.; Shrestha, J.; Wombacher, A.; Burlando, P. Modern comprehensive approach to monitor the morphodynamic evolution of a restored river corridor. Hydrol. Earth Syst. Sci. 2011, 15, 1197-1212. [CrossRef]

110. Feld, C.K.; Sousa, J.P.; da Silva, P.M.; Dawson, T.P. Indicators for biodiversity and ecosystem services: Towards an improved framework for ecosystems assessment. Biodivers. Conserv. 2010, 19, 2895-2919. [CrossRef]

111. Stähly, S.; Gostner, W.; Franca, M.J.; Robinson, C.T.; Schleiss, A.J. Sampling sufficiency for determining hydraulic habitat diversity. J. Ecohydraulics 2018, 3, 130-144. [CrossRef]

112. Schroff, R.; Mörtl, C.; Cesare, G. De ultrasonic doppler flow velocity measurements as a co-indicator for the eco-morphological assessment in a residual flow reach. In Proceedings of the 13th International Symposium on Ultrasonic Doppler Methods for Fluid Mechanics and Fluid Engineering, Zurich, Switzerland, 13-15 June 2021.

113. Schroff, R.; Mörtl, C.; De Cesare, G. Wirkungskontrolle einer sedimentzugabe: Habitatvielfalt und kolmation [eco-morphological evaluation of a sediment augmentation measure]. WasserWirtschaft 2021, 9, 68-76. [CrossRef]

114. Rickenmann, D. Bedload transport measurements with geophones, hydrophones, and underwater microphones (passive acoustic methods). In Gravel-Bed Rivers: Process and Disasters; Tsutsumi, D., Laronne, J.B., Eds.; John Wiley \& Sons, Ltd: Chichester, UK, 2017; pp. 185-208. ISBN 9781118971437.

115. Rennie, C.D.; Millar, R.G.; Church, M.A. Measurement of bed load velocity using an acoustic doppler current profiler. J. Hydraul. Eng. 2002, 128, 473-483. [CrossRef]

116. Bakker, M.; Gimbert, F.; Geay, T.; Misset, C.; Zanker, S.; Recking, A. Field application and validation of a seismic bedload transport model. J. Geophys. Res. Earth Surf. 2020, 125, 1-23. [CrossRef]

117. Woolsey, S.; Capelli, F.; Gonser, T.; Hoehn, E.; Hostmann, M.; Junker, B.; Paetzold, A.; Roulier, C.; Schweizer, S.; Tiegs, S.D.; et al. A strategy to assess river restoration success. Freshw. Biol. 2007, 52, 752-769. [CrossRef]

118. Pander, J.; Geist, J. Ecological indicators for stream restoration success. Ecol. Indic. 2013, 30, 106-118. [CrossRef] 